Nama:ISMAIL

Nim:10200120156

KIs:HTND

Jurnal Kewarganegaraan

Nama Jurnal

Jurnal Kewarganegaraan

Inisial

JK

Terbit

2 kali dalam setahun (Juni dan Desember)

P-ISSN

1978-0184

E-ISSN

2723-2328

Penerbit

Program Sarjana PPKN

Editor-in-Chief

T Heru Nurgiansah, M.Pd

Jurnal Kewarganegaraan terbit 2 kali dalam 1 tahun 
pada bulan Juni dan

Desember. Ruang Lingkup artikel mencakup :

1 Pendidikan Pancasila dan Pendidikan

Kewarganegaraan

2 Penddikan Karakter dan Pendidikan Antikorupsi

3 Pendidikan

Multikultural

4 Pendidikan Politik dan Pendidikan Hukum

5 Belajar dan

Pembelajaran

6 Kurikulum PPKN dan

Penelitian Tindakan Kelas

7 Media dan Model

Pembelajaran

Informasi

Belum ada informasi yang diterbitkan.

Lebih banyak informasi... 
Vol 5, No 1 (2021): Jurnal Kewarganegaraan

Daftar Isi

CANDI SIMANGAMBAT

SEBAGAI MEDIA

MEMBANGUN KARAKTER

PESERTA DIDIK YANG CINTA

PENINGGALAN

BERSEJARAH

Suratno Suratno, (Institut

Kesehatan Deli Husada Deli

Tua )

PDF

$1-5$

10.31316/jk.v5i1.1388

Abstract views : 26 | PDF

views : 15

IMPLEMENTASI PANCASILA SEBAGAI DASAR NEGARA

Puji Ayu Handayani,

(Universitas Pendidikan

Indonesia ) 
Dinie Anggraenie Dewi,

(Universitas Pendidikan

Indonesia )

PDF

$6-12$

10.31316/jk.v5i1.1439

Abstract views : 118 | PDF

views : 81

PERSEPSI MAHASISWA/I

TERHADAP WACANA

AMANDEMEN UUD NRI

1945 (Survei terhadap

Mahasiswa STEI ITB

Angkatan 2018)

Hendra Chayadi S., (Institut

Teknologi Bandung

Indonesia)

Mohamad Alamsyah,

(Institut Teknologi Bandung

Indonesia)

M. Izzrul Izzrufi, (Institut

Teknologi Bandung

Indonesia)

Selma Racinta L., (Institut 
Teknologi Bandung

Indonesia)

Epin Saepudin, (Institut

Teknologi Bandung

Indonesia)

PDF

$13-20$

10.31316/jk.v5i1.1440

Abstract views : 59 | PDF

views : 30

KONSTRUKSI EDUKASI BAGI

WARGA NEGARA MUDA

PADA AKUN MEDIA SOSIAL

TWITTER @asumsico

Chris Apandie, (Institut

Agama Kristen Negeri

Palangka Raya )

PDF

21-29

10.31316/jk.v5i1.1291

Abstract views : 19 | PDF

views : 8

PUDARNYA NILAI-NILAI

PANCASILA DALAM 
KEHIDUPAN MASYARAKAT

DI ERA GLOBALISASI

Ega Regiani, (Universitas Pendidikan Indonesia )

Dinie Anggraenie Dewi, (Universitas Pendidikan Indonesia )

PDF

30-38

10.31316/jk.v5i1.1402

Abstract views : 155 | PDF views : 129

MODEL PEMBELAJARAN MAKE A MATCH UNTUK MENINGKATKAN HASIL BELAJAR PENYESUAIAN DIRI DENGAN LINGKUNGAN PADA SISWA

Sumarni Sumarni, (SD N 1 Baturetno )

PDF

39-44

10.31316/jk.v5i1.1281

Abstract views : $20 \mid$ PDF 
views : 2

PEMAKNAAN MAHASISWA

\section{TERHADAP NARASI}

KONFLIK BERAGAMA

Silvia Rahmelia, (Institut

Agama Kristen Negeri

Palangka Raya )

PDF

45-54

10.31316/jk.v5i1.1288

Abstract views : 28 | PDF

views : 15

PENERAPAN METODE

STUDENT TEAMS -

ACHIEVEMENT DIVISION

(STAD) SEBAGAI UPAYA

MENINGKATKAN HASIL

BELAJAR

Eny Sutarti, (SD N 1

Belikurip )

PDF

$55-61$

10.31316/jk.v5i1.1280

Abstract views : 22 | PDF 
views : 7

PENGGUNAAN MEDIA SOSIAL INSTAGRAM PADA MATERI BUDAYA POLITIK GUNA MEMBANGUN CIVIC PARTICIPATION Ismaya Indri Astuti, (Kementerian Perindustrian (BPSDMI - SMK SMAK Padang) ) PDF $62-70$

Abstract views : 43 | PDF views : 44

PENINGKATAN KEMAMPUAN MENYUSUN RPP PEMBELAJARAN KOOPERATIF MELALUI PROGRAM SUPERVISI AKADEMIK BAGI GURU KELAS Murniyati Murniyati, (SD N 2 Selomarto ) PDF 
71-76

10.31316/jk.v5i1.1330

Abstract views : 10 | PDF

views : 5

PENINGKATAN

KEMAMPUAN

PENGGUNAAN MICROSOFT

OFFICE 365 MELALUI

PELATIHAN DAN SIMULASI

PADA GURU SEKOLAH

DASAR

Binti Ngatmiyatun, (SD N 3

Belikurip )

PDF

77-85

10.31316/jk.v5i1.1279

Abstract views : 40 | PDF

views : 18

PENINGKATAN

PENGGUNAAN PAST TENSE

DALAM TEXT RECOUNT

MELALUI MODEL STAD

PADA SISWA

Dewi Khotidjah, (SMP Negeri 
1 Giriwoyo )

PDF

86-91

10.31316/jk.v5i1.1266

Abstract views : 11| PDF

views : 3

UPAYA MENINGKATKAN

HASIL BELAJAR SISWA

MENGGUNAKAN METODE

SNOWBALL THROWING

Kurnia Emi Priyastuti, (SD

Negeri 2 Platarejo )

PDF

92-100

10.31316/jk.v5i1.1400

Abstract views : 23 | PDF

views : 9

UPAYA MENINGKATKAN

KEMAMPUAN GURU DALAM

MENYUSUN RPP DARING

MELALUI ACTIVE

KNOWLEDGE SHARING

Wasito Wasito, (SD N 2

Belikurip ) 
101-106

10.31316/jk.v5i1.1283

Abstract views : 57 | PDF

views : 21

UPAYA MENINGKATKAN

KINERJA GURU DALAM

MENYUSUN RPP MELALUI

SUPERVISI AKADEMIK

\section{SECARA PERIODIK}

Sarwantinah Sarwantinah, (SD N 2 Gambiranom )

PDF

$107-112$

10.31316/jk.v5i1.1286

Abstract views : 18 | PDF

views : 2

UPAYA MENINGKATKAN

KOMPETENSI GURU DALAM

PENGUASAAN KURIKULUM

2013 MELALUI IN SERVICE

\section{TRAINING}

Martinus Widodo, (SD N 2

Sendangrejo ) 
113-119

10.31316/jk.v5i1.1284

Abstract views : 15 | PDF

views : 6

UPAYA MENINGKATKAN

KOMPETENSI

PENYUSUNAN RPP

BERKARAKTER MELALUI

PRAKTIK UNJUK KERJA

Sareh Joko Pitoyo, (SD N 3

Baturetno )

PDF

$120-126$

10.31316/jk.v5i1.1285

Abstract views : 23 | PDF

views : 1

UPAYA MENINGKATKAN

MINAT DAN KEMAMPUAN

MENYUSUN RPP PADA

GURU KELAS MELALUI

SUPERVISI AKADEMIK

Sutarman Sutarman, (UPT

Dinas Pendidikan Kecamatan 
Slogohimo )

PDF

127-134

10.31316/jk.v5i1.1386

Abstract views : 10 | PDF

views : 4

UPAYA PENINGKATAN

KEAKTIFAN BELAJAR DAN

KETERAMPILAN TENIS

MEJA MENGGUNAKAN

METODE LATIHAN

Tinuk Suprihatin, (SD Negeri

6 Baturetno )

PDF

135-143

10.31316/jk.v5i1.1387

Abstract views : 18 | PDF

views : 8

UPAYA PENINGKATAN

KOMPETENSI

PENGGUNAAN WHATSAPP

SEBAGAI MEDIA

PEMBELAJARAN JARAK

JAUH MELALUI IN HOUSE 
TRAINING

Sarno Sarno, (SD N 7

Baturetno )

PDF

144-151

10.31316/jk.v5i1.1282

Abstract views : 21 | PDF

views : 7

IMPLEMENTASI NILAI-NILAI

PANCASILA SEBAGAI

KARAKTER DASAR PARA

GENERASI MUDA DALAM

MENGHADAPI ERA

REVOLUSI INDUSTRIAL 4.0

Regina Nurul Sakinah,

(Universitas Pendidikan

Indonesia )

Dinie Anggraenie Dewi,

(Universitas Pendidikan

Indonesia )

PDF

152-167

10.31316/jk.v5i1.1432

Abstract views : 282 | PDF 
views : 103

PERAN PKN MENGATASI FENOMENA KECINTAAN PRODUK LUAR YANG

TERJADI DI INDONESIA

Detania Hidapenta,

(Universitas Pendidikan Indonesia )

Dinie Anggraenie Dewi, (Universitas Pendidikan Indonesia )

PDF

168-175

10.31316/jk.v5i1.1401

Abstract views : 31 | PDF

views : 22

IMPLEMENTASI NILAI

PANCASILA DALAM

MENUMBUHKEMBANGKAN

WAWASAN KEBANGSAAN

DI KEHIDUPAN BANGSA

INDONESIA

Siti Aisyah Nurfatimah,

(Universitas Pendidikan 
Indonesia )

Dinie Anggraenie Dewi, (Universitas Pendidikan Indonesia )

PDF

$176-183$

10.31316/jk.v5i1.1446

Abstract views : 97 | PDF

views : 51

IMPLEMENTASI NILAI-NILAI

PANCASILA DALAM

MENINGKATKAN SUMBER

DAYA MANUSIA INDONESIA

Amanda Ramadhan Firdaus,

(Universitas Pendidikan

Indonesia )

Dinie Anggraenie Dewi,

(Universitas Pendidikan

Indonesia )

PDF

184-191

10.31316/jk.v5i1.1447

Abstract views : 65 | PDF

views : 39 
IMPLEMENTASI PANCASILA

DALAM MENGHADAPI

MASALAH RASISME DAN

DISKRIMINASI

Zihan Suryani, (Universitas

Pendidikan Indonesia )

Dinie Anggraenie Dewi,

(Universitas Pendidikan

Indonesia )

PDF

$192-200$

10.31316/jk.v5i1.1448

Abstract views : 183 | PDF

views : 176

PENGAMALAN BUTIR

PANCASILA: PERWUJUDAN

IMPLEMENTASI PANCASILA

SEBAGAI ETIKA DALAM

HIDUP BERMASAYARAKAT

Leni Yulia, (Universitas

Pendidikan Indonesia )

Dinie Anggraenie Dewi,

(Universitas Pendidikan

Indonesia ) 
201-211

10.31316/jk.v5i1.1449

Abstract views : 97 | PDF

views : 97

IMPLEMENTASI NILAI

PANCASILA SEBAGAI

LANDASAN BHINNEKA

TUNGGAL IKA

Amalia Dwi Pertiwi,

(Universitas Pendidikan Indonesia )

Dinie Anggraenie Dewi,

(Universitas Pendidikan

Indonesia )

PDF

212-221

10.31316/jk.v5i1.1450

Abstract views : 59 | PDF

views : 36

PENERAPAN NILAI NILAI

PANCASILA DALAM

KEHIDUPAN SEHARI HARI

DAN SEBAGAI PENDIDIKAN 
KARAKTER

Yohana R. U. Sianturi,

(Universitas Pendidikan

Indonesia )

Dinie Anggraenie Dewi,

(Universitas Pendidikan

Indonesia )

PDF

222-231

10.31316/jk.v5i1.1452

Abstract views : 227 | PDF

views : 74

IMPLEMENTASI NILAI

PANCASILA SEBAGAI

TINJAUAN ATAS

MENTALITAS ANAK

BANGSA INDONESIA

Fajriyatur Robi'ah,

(Universitas Pendidikan

Indonesia )

Dinie Anggraenie Dewi,

(Universitas Pendidikan

Indonesia )

PDF 
$232-238$

10.31316/jk.v5i1.1461

Abstract views : 40 | PDF

views : 18

PENTINGNYA

IMPLEMENTASI NILAI

PANCASILA AGAR TIDAK

TERJADI PENYIMPANGAN

DALAM MASYARAKAT LUAS

Aulia Nur Hakim,

(Universitas Pendidikan

Indonesia )

Dinie Anggraenie Dewi,

(Universitas Pendidikan

Indonesia )

PDF

239-248

10.31316/jk.v5i1.1391

Abstract views : 54 | PDF

views : 42

PENDIDIKAN

KEWARGANEGARAAN:

MEMBANGUN

MASYARAKAT DEMOKRASI 
YANG BERKEADABAN DARI

SAAT INI

Bunga Bhagasasih Al-

Khansa, (Universitas

Pendidikan Indonesia )

Dinie Anggraenie Dewi,

(Universitas Pendidikan

Indonesia )

PDF

249-258

10.31316/jk.v5i1.1429

Abstract views : 32 | PDF

views : 17

IMPLEMENTASI NILAI NILAI

PANCASILA MELALUI

PENDIDIKAN

KEWARGANEGARAAN DI

SEKOLAH DAN DI

MASYARAKAT

An Nisaa'an Najm Al Inu,

(Universitas Pendidikan

Indonesia )

Dinie Anggraenie Dewi,

(Universitas Pendidikan 
Indonesia )

PDF

259-267

10.31316/jk.v5i1.1383

Abstract views : 42 | PDF

views : 21

PENGARUH PENDIDIKAN

KEWARGANEGARAAN

DALAM MEMBANGUN

KARAKTER GENERASI

MUDA

Shafarina Nidaul Aulia,

(Universitas Pendidikan

Indonesia )

Dinie Anggraenie Dewi,

(Universitas Pendidikan

Indonesia )

PDF

268-275

10.31316/jk.v5i1.1354

Abstract views : 23 | PDF

views : 5

PENGARUH PENGGUNAAN

GADGET TERHADAP 
KEMAMPUAN INTERAKSI

SOSIAL SISWA SEKOLAH

DASAR

Yohana R. U. Sianturi,

(Universitas Pendidikan

Indonesia )

PDF PDF

276-284

10.31316/jk.v5i1.1430

Abstract views : 25 | PDF

views : 3 | PDF views : 7

PERSEPSI GURU TERHADAP

PENILAIAN AUTENTIK

KURIKULUM 2013 DI SMPN

3 KOMODO LABUAN BAJO

MANGGARAI BARAT

Vinsensius Zwei De Orans

Jemalu, (Universitas

Cokroaminoto Yogyakarta )

Heri Kurnia, (Universitas

Cokroaminoto Yogyakarta )

Triwahyu Budiutomo, (IKIP PGRI Wates ) 


\section{Jurnan kewenangan}

konstitusi

KEDUDUKAN DAN

WEWENANG MAHKAMAH

KONSTITUSI DALAM

SISTEM HUKUM

KETATANEGARAAN

INDONESIA

Oleh : Nanang Sri Darmadi, $\mathrm{SH} ., \mathrm{MH}$

Dosen Fakultas Hukum

UNISSULA

Abstract

Fundamental changes in the 1945 is the amendment of Article 1 paragraph (2) as follows: "Sovereignty belongs to the people and carried out according to the Constitution". Change the 1945 Constitution has given rise to the Constitutional 
Court. By the Constitutional

Court, the constitution

guaranteed as the supreme law that can be enforced as it should. The Constitutional Court in its development, it is feared will be the agency that has authority super body.Particularly in resolving the matter related to its authority, the Constitutional Court can unilaterally interpret the Constitution without being questioned, other than that produced the Constitutional Court ruling is final and binding, so that when there is one party who feels aggrieved by the decision of the

Constitutional Court cannot make the effort for From the approach used in this study is normative 
juridical, because the study was conducted by

examining library materials

or secondary data relating to the status and authority of the Constitutional Court in constitutional legal system of Indonesia. Specifications of this research is descriptive analysis, which is expected to give a detailed overview, systematic, and comprehensive on all matters relating to the object to be examined. The data used in this study is secondary data, it means the data obtained from library materials collected through the study of literature and documentary studies, which are then analyzed qualitatively.

The conclusion of this study 
is that the formation of the

Constitutional Court in

Indonesia is inseparable from the development of judicial review occurring in several countries in the world, especially during the implementation of judicial review which was pioneered by John Marshall in Marbury versus Madison case.Thinking about the importance of the

Constitutional Court in Indonesia has emerged during the discussion of the draft Constitution in BPUPKI, then the idea of judicial review of the need to reemerge during the discussion draft Judicial Power Act (Act No. 14 of 1970). At the time of the discussion of the 1945 
changes in the era

reformation, the opinion of the importance of the

Constitutional Court appeared. Ultimately, the

Third Amendment to the 1945 to be of the

Constitutional Court, which serves as the guardian of the Constitution and constitutional interpretation. other law.

Keywords: Constitutional Court, The Status and Authority in the Constitution

KedudukandanWewenangM ahkamahKonstitusi....

(NanangSriDarmadi) 667 A. PENDAHULUAN

Sistem ketatanegaraan pada dasarnya mengandung dua aspek, yaitu aspek yang 
berkenaan dengan

kekuasaan lembaga-

lembaga negara beserta

hubungannya satu sama lain

di antara lembaga-lembaga

negara tersebut serta

hubungan-hubungan antara lembaga-lembaga negara dengan warga negara.

Kedua aspek tersebut dapat dilihat dalam konstitusi

suatu negara.1

Suatu konstitusi merupakan sebuah sistem hukum, tradisi, dan konvensi yang kemudian membentuk suatu sistem konstitusi atau ketatanegaraan suatu negara. Suatu sistem ketatanegaraan mencerminkan fungsi-fungsi yang terdapat dalam hukum ketatanegaraan. Fungsifungsi tersebut di antaranya 
adalah pembentukan fungsi

lembaga, pembagian

kewenangan, dan

pengaturan batas-batas di

antara jabatan satu sama

lain, serta hubungan antara jabatan dan warga negara.

Ketiga fungsi tersebut, yakni fungsi pembentukan,

pembagian, dan pengaturan

merupakan fungsi-fungsi

mengoperasikan sebuah

sistem ketatanegaraan

berdasarkan norma-norma,

aturan-aturan konstitusi,

serta prinsip- prinsip

konstitusionalisme dan

negara hukum dalam suatu konstitusi.2

Fungsi-fungsi tersebut, akan dapat berjalan manakala ketiga kekuasaan yakni legislatif, eksekutif, dan yudikatif dijalankan melalui 
prinsip pemisahan

kekuasaan (separation of power) dan checks and balances.

Sistem ketatanegaraan yang diatur dalam konstitusi suatu negara dan dalam format politik yang demokratis serta sistem pemisahan kekuasaan negara dan checks and balances tidak terlepas

1 Zainal Arifin Hoesein, 2009, Judicial Review di Mahkamah Agung RI, Tiga Dekade Pengujian Peraturan Perundang-undangan, Raja Grafindo Persada, Jakarta, h. 26.

2 lbid., h. 26. 668

Jurnal Hukum Vol XXVI, No. 2, Agustus 2011 
dari adanya prinsip dan

pelaksanaan wewenang

untuk menguji atau

pengujian peraturan

perundang-undangan

(judicial review).

Di beberapa negara

demokrasi pada umumnya,

kehadiran sistem pengujian

konstitusi diterima sangat

baik. Tidak hanya di

kalangan akademisi, maupun

praktisi bahkan di kalangan

kekuasaan peradilan sendiri

pun sangat antusias

menyambut kehadiran

sistem pengujian konstitusi

tersebut, karena dengan

kehadiran sistem pengujian

konstitusi tersebut,

dianggap sebagai cara

negara hukum modern untuk mengendalikan dan

mengimbangi (check and 
balance) kekuasaan para pejabat pemerintah yang cenderung menjadi

sewenang-wenang.

Konsep judicial review itu sendiri sebenarnya dilihat sebagai hasil perkembangan modern tentang sistem pemerintahan demokratis yang didasarkan atas ide-ide negara hukum (rule of law), prinsip pemisahan

kekuasaan (separation of power), serta perlindungan dan pemajuan hak asasi manusia (the protection of fundamental rights).3 Pada dasarnya juicial review hanya dapat dijalankan

sebagaimana mestinya dalam negara yang menganut supremasi hukum dan bukan supremasi parlemen. Dalam negara 
yang menganut sistem

supremasi parlemen, produk hukum yang dihasilkan tidak dapat diganggu gugat,

karena parlemen merupakan bentuk representasi dari

kedaulatan rakyat.4

Judicial review atau

contitutional review di

dalamnya terdapat 2 (dua)

cakupan tugas pokok yang

meliputi : Pertama,

menjamin berfungsinya

sistem demokrasi dalam

hubungan perimbangan

peran antara kekuasaan

legislatif, eksekutif, dan

yudikatif supaya tidak terjadi pemusatan kekuasaan oleh

satu cabang kekuasaan

terhadap

3 Herbert Hausmaninger,

2003, The Austrian Legal

Sistem,Wien, h. 139 dalam 
Jimly Asshiddiqie, 2010,

Model-model Pengujian

Konstitutional di Berbagai

Negara, Sinar Grafika,

Jakarta, (selanjutnya

disingkat Jimly Asshiddiqie

I), h. 8.

4 Zainal Arifin Hoesein, op.cit., h. 52-53.

KedudukandanWewenangM ahkamahKonstitusi....

(NanangSriDarmadi) 669

cabang kekuasaan lainnya;

Kedua, melindungi setiap individu warga negara dari penyalahgunaan kekuasaan oleh lembaga negara yang merugikan hak-hak dasar yang dijamin dalam konstitusi.5

Di dunia ide pengujian konstitusional berkembang sedemikian luas, penerimaan 
dan praktik di masing-

masing negara tentunya

berbeda-beda antara negara yang satu dengan lainnya,

yang jelas terus

berkembangnya ide pengujian konstitusional tersebut dalam teori dan praktik tidak lepas dari naik turunnya perjalanan sejarah. Tahap-tahap perkembangan tersebut bisa dilihat dalam bentangan waktu yang mana mulai dari gagasan-gagasan tradisional sampai yang paling modern.

Di Indonesia, perubahan terhadap Undang-Undang

Dasar 1945 memberikan warna baru dalam sistem ketatanegaraan. Salah satu perubahan mendasar dalam Undang-Undang Dasar 1945 adalah SHUXEDKDQ 3DVDO 


\section{D।DW |DQJ EHUEXQ|L}

3.HGDXODWDQ EHUDGD

GL tangan rakyat dan

dilaksanakan menurut

Undang-8QGDQJ 'DVDU¥

Ketentuan ini membawa implikasi bahwa kedaulatan rakyat tidak lagi dilakukan sepenuhnya oleh Majelis Permusyawaratan Rakyat, tetapi dilakukan menurut ketentuan Undang-Undang Dasar.6 Selain hal tersebut perubahan Undang-Undang

Dasar 1945 telah melahirkan suatu lembaga negara yang berfungsi sebagai pengawal dan penafsir konstitusi, yakni dengan hadirnya Mahkamah Konstitusi. Secara konseptual, gagasan pembentukan Mahkamah Konstitusi adalah untuk menyelenggarakan peradilan 
guna menegakkan hukum

dan keadilan. Mengadili

tingkat pertama dan terakhir

yang putusannya

5 Jimly Asshiddiqie I, loc.cit.

6 Jimly Asshiddiqie, 2006,

Hukum Tata Negara dan

Pilar-pilar Demokrasi,

Konstitusi Press, Jakarta, h.

318.

670 Jurnal Hukum Vol XXVI,

No. 2, Agustus 2011

bersifat final dalam hal

menguji undang-undang

terhadap Undang- Undang

Dasar 1945, dan

kewenangan lain yang

dimilikinya.7

Dalam Mahkamah Konstitusi inilah, konstitusi dijamin sebagai hukum tertinggi yang dapat ditegakkan sebagaimana mestinya, yang 
dalam menjalankan

fungsinya sebagai pengawal konstitusi, Mahkamah

Konstitusi Republik

Indonesia dilengkapi dengan lima kewenangan. Empat kewenangannya, yaitu (i) menguji konstitusionalitas undang-undang, memutus sengketa kewenangan konstitusional antar lembaga negara, (iii) memutus perselisihan hasil pemilihan umum, (iv)

memutus pembubaran partai politik, dan satu kewajiban yaitu (v) memutus pendapat Dewan Perwakilan Rakyat tentang tuduhan presiden dan wakil presiden melanggar hukum atau tidak sebagaimana ditentukan dalam Undang-Undang Dasar 1945. 
Sebagai penafsir tunggal atas konstitusi, Mahkamah Konstitusi dalam perkembangannya oleh sebagian penggiat hukum dikhawatirkan akan menjadi lembaga yang memiliki kewenangan super body.

Khususnya dalam menyelesaikan perkara terkait dengan kewenangan yang dimilikinya, Mahkamah Konstitusi secara sepihak bisa menafsirkan UndangUndang Dasar tanpa dapat dipersoalkan, selain itu putusan yang dihasilkan Mahkamah Konstitusi bersifat final dan mengikat, sehingga ketika ada salah satu pihak yang merasa dirugikan dengan putusan Mahkamah Konstitusi tidak bisa melakukan upaya 
hukum yang lain.

Kewenangan

menginterpretasikan

konstitusi sebagai pijakan

penguji undang-undang oleh

hakim konstitusi dirasa

sangat begitu besar,

sehingga dapat membuka

peluang kesewenang-

wenangan hakim konstitusi

menafsirkan tanpa rasa

keadilan terhadap persoalan

7 Ahmad Syahrizal, 2006,

Peradilan Konstitusi, Suatu

Studi tentang Adjudikasi

Konstitusional Sebagai

Mekanisme Penyelesaian

Sengketa Normatif, Pradnya

Paramita, Jakarta, h. 263.

KedudukandanWewenangM

ahkamahKonstitusi....

(NanangSriDarmadi) 671

hukum yang dimohonkan, 
sehingga berdasarkan kewenangan hakim konstitusi yang sangat besar tersebut, walaupun ada aturan dalam pengujian undang-undang, Mahkamah Konstitusi dapat mengesampingkan ramburambu hukum tersebut. Misalkan dalam perkara pengujian Undang-undang Nomor 14 Tahun 1985

Tentang Mahkamah Agung yang dimohonkan oleh seorang hakim Pengadilan Negeri di Padang (Perkara No.004/PUU-I/2003).

Mahkamah Konstitusi tercatat pernah menguji perkara tersebut walaupun jelas dalam Pasal 50

Undang-undang Tentang Mahkamah Konstitusi menyatakan bahwa undang- 
undang yang dapat

dimohonkan untuk diuji

adalah undang-undang yang

diundangkan setelah

perubahan Undang-Undang

Dasar 1945.8

Dalam melakukan

pemeriksaan perkara di

persidangan, kerap kali

hakim konstitusi

mendapatkan kendala terkait dengan kurang memadainya dokumentasi Dewan

Perwakilan Rakyat dalam risalah pembahasan

rancangan undang-undang,

sehingga menyebabkan

hakim konstitusi terhambat

memahami konteks

pembentukan undang-

undang yang berimplikasi

pada tidak maksimalnya

pengambilan putusan cepat

dan tepat seperti keinginan 
pemohon, karena tidak

didukung oleh data yang

valid sebagai dasar putusan.

Selain hal tersebut di atas,

Mahkamah Konstitusi juga

belum memiliki pengawasan

internal yang baik dalam

menjalankan

kewenangannya. Mahkamah

Konstitusi belum memiliki

pengawasan internal yang

mampu untuk mendeteksi

terjadinya pelanggaran

maupun kelemahan

organisasi, yang ada hanya

mekanisme pengawasan

yang bersifat hierarkis

struktural dan tidak

melibatkan seluruh

komponen organisasi

sehingga pengawasan tidak partisipatoris dan efektif.

Keadaan itu juga diperkuat

dengan 
8 Refly Harun et al., 2004,

Menjaga Denyut Konstitusi, Konstitusi Perss, Jakarta, h. 231.

672 Jurnal Hukum Vol XXVI, No. 2, Agustus 2011

gencarnya pemberitaan di media tentang praktik suap terhadap hakim konstitusi yang diduga mampu mempengaruhi putusannya dan menurunkan kewibawaan peradilan di Mahkamah Konstitusi.

Sebagaimana dikemukakan oleh Alexander Hamilton bahwa diperlukan ketabahan yang luar biasa bagi para hakim dalam menjalankan tugas mereka sebagai pelindung setia konstitusi, sementara pelanggaran legislatif terhadap konstitusi 
diawali dengan suara masyarakat mayoritas.9

Berdasarkan uraian di atas, maka yang menjadi permasalahan dalam penelitian ini adalah mengenai sejarah pembentukan Mahkamah Konstitusi di Indonesia serta dasar filosofis, yuridis, dan sosiologis tentang kedudukan dan wewenang Mahkamah Konstitusi.

\section{B. METODEPENELITIAN}

Metode pendekatan yang digunakan dalam penelitian ini adalah pendekatan yuridis normatif, karena masalah yang akan diteliti ada hubungannya dengan sejarah pembentukan Mahkamah Konstitusi dan dasar filosofis, yuridis, maupun sosiologis tentang 
kedudukan dan wewenang Mahkamah Konstitusi dalam sistem hukum

ketatanegaraan Indonesia.

Spesifikasi penelitian ini bersifat deskriptif analisis, karena diharapkan mampu memberi gambaran secara rinci, sistematis, dan menyeluruh dengan obyek yang akan diteliti, yakni kaitannya dengan kedudukan dan wewenang Mahkamah Konstitusi.

Data yang digunakan dalam penelitian ini adalah data sekunder, yaitu data yang diperoleh dari bahan-bahan pustaka.Data yang diperoleh dalam penelitian, kemudian akan dianalisis secara kualitatif, yaitu data yang diperoleh kemudian akan disusun secara sistematis 
yang selanjutnya akan dianalisis secara kualitatif untuk

9 Leonard W. Levy, 2005, Judicial Review, Sejarah Kelahiran, Wewenang, dan Fungsinya dalam Negara Demokrasi, Nuansa, Bandung, h. 98. KedudukandanWewenangM ahkamahKonstitusi.... (NanangSriDarmadi) 673

mencapai kejelasan mengenai kedudukan dan wewenang Mahkamah

Konstitusi dalam sistem

hukum ketatanegaraan Indonesia.

C. HASIL DAN

PEMBAHASAN

Sejarah Pembentukan

Mahkamah Konstitusi di Indonesia 
Pelaksanaan judicial review yang dipelopori oleh John Marshall memberikan pengaruh yang sangat penting bagi negara lain di dunia, termasuk di Indonesia dengan berdirinya

Mahkamah Konstitusi

Indonesia. Alhasil, kehidupan ketatanegaraan Indonesia mengalami perubahan mendasar, yakni ketika dimulainya perubahan Undang-Undang Dasar 1945 pada tahun 1999. Perubahan Undang- Undang Dasar 1945 menjadi catatan sejarah ketatanegaraan Indonesia, karena fondasi ketatanegaraan mengalami perubahan drastis, hampir meliputi berbagai bidang kehidupan.

Sejak tahun 2001, secara 
resmi Amandemen Ketiga

Undang- Undang Dasar

1945 (melalui Sidang

Tahunan Majelis

Permusyawaratan Rakyat

Tahun 2001) menerima

masuknya Mahkamah

Konstitusi di dalam Undang-

Undang Dasar tersebut.10

Pembentukan Mahkamah

Konstitusi menandai era

baru dalam sistem

kekuasaan kehakiman di

Indonesia. Beberapa wilayah

yang tadinya tidak tersentuh

(untouchable) oleh hukum,

seperti masalah judicial

review terhadap undang-

undang, sekarang dapat

dilakukan oleh Mahkamah

Kontitusi.11

Majelis Permusyawaratan

Rakyat melakukan

perubahan yang 
fundamental terhadap Pasal

24 Undang-Undang Dasar 1945 dengan cara

mengubah Pasal 24 dan

menambahnya dengan Pasal

24A, Pasal 24B, dan Pasal

$24 \mathrm{C}$ yang di dalamnya

memuat dua lembaga baru,

yaitu Mahkamah Konstitusi

dan Komisi Yudisial.

10 Moh.Mahfud MD, 2010,

Membangun Politik Hukum,

Menegakkan Konstitusi, Raja

Grafindo Persada, Jakarta,

h. 133.

11Bambang Sutiyoso, 2009,

Tata Cara Penyelesaian

Sengketa di Lingkungan

Mahkamah Konstitusi, UII

Press, Yogyakarta, h. 1.

674 Jurnal Hukum Vol XXVI,

No. 2, Agustus 2011

Indonesia merupakan negara 
ke-78 yang membentuk

Mahkamah Konstitusi.

Pembentukan Mahkamah

Konstitusi sendiri merupakan fenomena negara modern abad ke-20,12 tatkala Perubahan Ketiga UndangUndang Dasar Negara Republik Indonesia, berdasarkan Pasal 24 ayat (2) Tahun 1945 juncto Pasal 24C Undang- Undang Dasar Negara Republik Indonesia, diputuskan dalam Rapat Paripurna Majelis

Permusyawaratan Rakyat Republik Indonesia.13 Pemikiran mengenai pentingnya suatu Mahkamah Konstitusi telah muncul dalam sejarah ketatanegaraan Indonesia sebelum merdeka. Pada saat pembahasan rancangan 
Undang-Undang Dasar di

Badan Penyelidik Usahausaha Persiapan

Kemerdekaan Indonesia (BPUPKI).

Ide perlunya judicial review, khususnya pengujian undang- undang terhadap Undang-Undang Dasar, kembali muncul pada saat pembahasan Rancangan Undang-undang Kekuasaan Kehakiman yang selanjutnya ditetapkan menjadi Undangundang Nomor 14 Tahun 1970 Tentang Pokok-Pokok Kekuasaan Kehakiman.

Pada saat pembahasan perubahan Undang-Undang Dasar 1945 dalam era reformasi, pendapat mengenai pentingnya Mahkamah Konstitusi muncul kembali. Perubahan 
Undang-Undang Dasar 1945 yang terjadi dalam era reformasi tersebut telah menyebabkan Majelis Permusyawaratan Rakyat tidak lagi berkedudukan sebagai lembaga tertinggi negara dan supremasi, tetapi beralih dari supremasi Majelis Permusyawaratan Rakyat kepada supremasi konstitusi.

Perubahan yang mendasar tersebut perlu adanya mekanisme institusional dan konstitusional serta hadirnya lembaga negara yang mengatasi kemungkinan sengketa antar lembaga negara yang kini

12 Mahkamah Konstitusi Republik Indonesia, 2010, Hukum Acara Mahkamah Konstitusi, Sekretariat 
Jenderal dan Kepaniteraan

Mahkamah Konstitusi,

Jakarta, h. 5.

13 Laica Marzuki, 2006,

6XGL ODPSLU GL

ODKNDPDK .RQVWLWXVL

5, 3-XGLFLDO 5HYLHZ¥

$\%$ HUDFDUD GL

ODKNDPDK .RQVWLWXVi),

Sekretariat Jenderal dan

Kepaniteraan Mahkamah

Konstitusi Republik

Indonesia, Jakarta, h. 7.

KedudukandanWewenangM ahkamahKonstitusi....

(NanangSriDarmadi) 675

676

telah menjadi sederajat serta saling mengimbangi dan saling mengendalikan (checks and balances).

Kehadiran Mahkamah

Konstitusi melalui perubahan 
ketiga Undang-Undang

Dasar 1945 dalam sidang tahunan Majelis

Permusyawaratan Rakyat (2001) memiliki dasar konstitusional yang kuat. Artinya, eksistensi, kedudukan, kewenangan, kewajiban, dan komposisi para hakim Mahkamah Konstitusi diatur dengan tegas dalam UndangUndang Dasar 1945.

Namun, dengan disahkannya Perubahan Ketiga UndangUndang Dasar 1945, tidak dengan sendirinya Mahkamah Konstitusi telah terbentuk. Untuk mengatasi kekosongan tersebut pada Perubahan Keempat

Undang-Undang Dasar 1945 ditentukan dalam Aturan Peralihan Pasal bahwa 
Mahkamah Konstitusi paling

lambat sudah harus

terbentuk pada 17 Agustus

2003. Sebelum terbentuk,

segala kewenangan

Mahkamah Konstitusi

dilakukan oleh Mahkamah

Agung.

Undang-undang Mahkamah

Konstitusi, yaitu Undang-

undang Nomor 24 Tahun

2003 disahkan pada 13

Agustus 2003. Waktu

pengesahan Undang-

undang Nomor 24 Tahun

2003 Tentang Mahkamah

Konstitusi inilah yang

ditetapkan sebagai hari

lahirnya Mahkamah

Konstitusi. Berdasarkan

Undang-undang Mahkamah

Konstitusi, pembentukan

Mahkamah Konstitusi segera dilakukan melalui rekrutmen 
hakim konstitusi oleh tiga lembaga negara, yaitu

Dewan Perwakilan Rakyat, presiden, dan Mahkamah Agung. Setelah melalui tahapan seleksi sesuai mekanisme yang berlaku pada masing-masing lembaga, akhirnya Dewan Perwakilan Rakyat, presiden, dan Mahkamah Agung menetapkan masing-masing tiga calon hakim konstitusi. Selanjutnya ditetapkan oleh presiden sebagai hakim konstitusi. sembilan hakim konstitusi pertama ditetapkan pada 15 Agustus 2003 dengan Keputusan Presiden Nomor 147/M

Tahun 2003. Pengucapan Jurnal Hukum Vol XXVI, No. 2, Agustus 2011 
sampah jabatan kesembilan

hakim tersebut dilakukan di

Istana Negara pada 16

Agustus 2003.

Keberadaan Mahkamah

Konstitusi sekaligus untuk

menjaga terselenggaranya

pemerintahan negara yang

stabil, dan juga merupakan

koreksi terhadap

pengalaman kehidupan

ketatanegaraan di masa lalu

yang ditimbulkan oleh tafsir

ganda terhadap konstitusi.14

Mahkamah Konstitusi

sebagai salah satu pelaku

kekuasaan kehakiman

diharapkan mampu

mengembalikan citra

lembaga peradilan di

Indonesia sebagai

kekuasaan kehakiman yang

merdeka yang dapat

dipercaya dalam 
menegakkan hukum dan keadilan.

Dasar Filosofis, Yuridis, dan Sosiologis tentang

Kedudukan dan Wewenang Mahkamah Konstitusi Mahkamah Konstitusi merupakan pelaku kekuasaan kehakiman yang merdeka untuk menyelenggarakan peradilan guna menegakkan hukum dan keadilan. Mahkamah Konstitusi dibentuk untuk menjamin konstitusi sebagai hukum tertinggi agar dapat ditegakkan, sehingga Mahkamah Konstitusi disebut dengan the guardian of the constitution.

Kedudukan Mahkamah

Konstitusi ini setingkat atau sederajat dengan Mahkamah Agung sebagai kekuasaan 
kehakiman yang merdeka15 dalam sistem ketatanegaraan Indonesia.

Dalam menjalankan kewenangannya, termasuk di dalamnya adalah menguji undang-undang terhadap undang-undang dasar, Mahkamah Konstitusi juga melakukan penafsiran konstitusi, sehingga Mahkamah Konstitusi juga disebut the Sole Interpreter of the Constitution.

14 Bambang Sutiyoso,

Desember 2010,

Pembentukan Mahkamah Konstitusi Sebagai Pelaku Kekuasaan Kehakiman di Indonesia, dalam Jurnal Konstitusi Volume 7 Nomor 6, Sekretariat Jenderal dan Kepaniteraan Mahkamah Konstitusi, Jakarta, h. 29. 
15 Miftakhul Huda,

September 2007, 380WUD

3HWLWD¥ GDODP

3HQJXMLDQ 8QGDQJ-

Undang, dalam Jurnal

Konstitusi Volume 4 Nomor

3, Mahkamah Konstitusi

Republik Indonesia, Jakarta,

h. 144.

KedudukandanWewenangM ahkamahKonstitusi....

(NanangSriDarmadi) 677

678

Sebagai lembaga penafsir tunggal konstitusi, banyak hal dalam mengadili menimbulkan akibat terhadap kekuasaan lain dalam kedudukan berhadaphadapan, terutama terhadap lembaga legislatif di mana produknya direview.

Kedudukan Mahkamah 
Konstitusi dalam sistem

ketatanegaraan Indonesia adalah sebagai lembaga negara yang menjalankan fungsi yudisial dengan kompetensi obyek perkara ketatanegaraan.

Keberadaan Mahkamah

Konstitusi dipahami sebagai pengawal konstitusi untuk memperkuat dasar-dasar konstitusionalisme dalam

Undang-Undang Dasar 1945. Oleh karena itu, Mahkamah Konstitusi mempunyai kewenangan dengan batasan yang jelas sebagai bentuk penghormatan atas konstitusionalisme. Batasbatas kewenangan yang dimiliki oleh Mahkamah Konstitusi sebagai salah satu lembaga yudisial merupakan 
bentuk terselenggaranya

sistem perimbangan

kekuasaan di antara

lembaga negara (checks and balances).

Mahkamah Konstitusi

sebagai salah satu pelaku

kekuasaan kehakiman

diharapkan mampu

mengembalikan citra

lembaga peradilan di

Indonesia sebagai

kekuasaan kehakiman yang

merdeka yang dapat

dipercaya dalam

menegakkan hukum dan

keadilan.

Dasar filosofis dari

wewenang dan kewajiban

Mahkamah Konstitusi adalah

keadilan substantif dan

prinsip-prinsip good

governance. Selain itu, teori-

teori hukum juga 
memperkuat keberadaan

Mahkamah Konstitusi

sebagai lembaga negara pengawal dan penafsir konstitusi. Kehadiran Mahkamah Konstitusi beserta segenap wewenang dan kewajibannya, dinilai telah merubah doktrin Jurnal Hukum Vol XXVI, No. 2, Agustus 2011

supremasi parlemen (parliamentary supremacy) dan menggantikan dengan ajaran supremasi konstitusi. 16

Keadilan substantif/keadilan materiil (substantive justice) merupakan al qist atau bagian yang wajar dan patut, tidak mengarahkan kepada persamaan, melainkan bagian yang patut, berpihak 
kepada yang benar. Dalam penerappan keadilan

substantif ini, pihak yang

benar akan mendapat

kemenangan sesuai dengan

bukti-bukti akan

kebenarannya.

Teori-teori yang menjadi dasar pentingnya reformasi konstitusi dan menjadi dasar wewenang serta kewajibah Mahkamah Konstitusi adalah teori kedaulatan negara, teori konstitusi, teori negara hukum demokrasi, teori kesejahteraan, teori keadilan, dan teori kepastian hukum.

Dasar yuridis wewenang Mahkamah Konstitusi berasal dari Undang-

Undang Dasar 1945 yang diatur dalam Pasal 7A, Pasal 78, dan Pasal 24C dan 
dijabarkan dengan Undangundang Nomor 24 Tahun 2003. Terhadap perorangan, kesatuan masyarakat adat sepanjang masih hidup, badan hukum publik atau privat, lembaga negara, partai politik, ataupun pemerintah dan Dewan Perwakilan Rakyat, jika hak dan/atau wewenang konstitusionalnya dirugikan, dapat mengajukan permohonan ke Mahkamah Konstitusi.

Mahkamah Konstitusi merupakan lembaga negara yang baru dalam sistem ketatanegaraan Indonesia hasil perubahan UndangUndang Dasar Negara Republik Indonesia Tahun 1945 yang dibentuk karena buruknya penyelenggaraan 
negara terutama pada masa orde baru, yang ditandai dengan maraknya korupsi, kolusi, dan nepotisme, markus (makelar kasus) sampai saat ini, dan dicampakkannya nilai16 Mariyadi Faqih, Juni 2010, Nilai-nilai Filosofi Putusan Mahkamah Konstitusi yang Final dan Mengikat, dalam Jurnal Konstitusi Volume 7 Nomor 3, Sekretarian Jenderal dan Kepaniteraan Mahkamah Konstitusi, Jakarta, h. 97.

KedudukandanWewenangM ahkamahKonstitusi.... (NanangSriDarmadi) 679

nilai keadilan hukum menjadi faktor yang dalam melakukan perubahan diberbagai bidang, terutama 


\section{sistem peradilan. 17}

Sebagai organ konstitusi, Mahkamah Konstitusi

didesain untuk menjadi pengawal dan penafsir undang-undang dasar melalui putusan-putusannya.

Dalam menjalankan tugas konstitusionalnya, Mahkamah Konstitusi berupaya mewujudkan visi kelembagaannya, yakni tegaknya konstitusi dalam rangka mewujudkan cita negara hukum dan demokrasi demi kehidupan kebangsaan dan kenegaraan yang bermartabat.

Visi tersebut menjadi pedoman bagi Mahkamah Konstitusi dalam menjalankan kekuasaan kehakiman yang diembannya secara merdeka dan 
bertanggung jawab sesuai dengan amanat Undang-

Undang Dasar Negara

Republik Indonesia Tahun

1945.

Mahkamah Konstitusi

membuka diri untuk

menerima permohonan dari

masyarakat yang merasa

hak-haknya dan

kewenangan

konstitusionalnya dilanggar akibat berlakunya suatu undang-undang.

D. SIMPULANDANSARAN

Simpulan

Sejarah pembentukan

Mahkamah Konstitusi di

Indonesia tidak terlepas dari perkembangan judicial review yang terjadi dibeberapa negara di dunia. Perkembangan judicial review yang paling 
berpengaruh terhadap keberadaan Mahkamah Konstitusi adalah pada saat Pelaksanaan judicial review yang dipelopori oleh John Marshall dalam kasus Marbury versus Madison. Pemikiran mengenai pentingnya suatu Mahkamah Konstitusi telah muncul dalam sejarah ketatanegaraan Indonesia sebelum

17 Indra Perwira, dkk.,

November 2010, Budaya Konstitusi (Constitutional Culture) Dalam UUD 1945 Perubahan Dikaitkan Dengan Gagasan Perubahan Kelima UUD 1945, dalam Jurnal Konstitusi Volume II Nomor 2, Mahkamah Konstitusi Republik Indonesia, Jakarta, h. 60. 
680 Jurnal Hukum Vol XXVI,

No. 2, Agustus 2011

merdeka. Pada saat

pembahasan rancangan

Undang-Undang Dasar di

Badan Penyelidik Usaha-

usaha Persiapan

Kemerdekaan Indonesia,

kemudian ide perlunya

judicial review kembali

muncul pada saat

pembahasan Rancangan

Undang-undang Kekuasaan

Kehakiman (Undang-undang

Nomor 14 Tahun 1970). Pada

saat pembahasan

perubahan Undang-Undang

Dasar 1945 dalam era

reformasi, pendapat

mengenai pentingnya

Mahkamah Konstitusi

muncul kembali.

Pada akhirnya, dengan 


\section{Amandemen Ketiga}

Undang-Undang Dasar 1945 yang dilakukan oleh Majelis Permusyawaratan Rakyat lahirlah sebuah lembaga negara baru, yakni Mahkamah Konstitusi, yang berfungsi sebagai penjaga konstitusi (the guardian of constitution) dan juga berperan sebagai penafsir konstitusi (the interpreter of constitution).

Eksistensi Mahkamah Konstitusi terwujud dalam melaksanakan tugas dan kewenangannya setelah Dewan Perwakilan Rakyat dan pemerintah menyetujui diundangkannya Undangundang Nomor 24 Tahun 2003 Tentang Mahkamah Konstitusi sebagai dasar pijak Mahkamah Konstitusi 
dalam penyelenggaraan pengujian konstusionalitas sesuai amanat UndangUndang Dasar 1945. Kedudukan Mahkamah Konstitusi dalam sistem ketatanegaraan Indonesia merupakan bagian dari kekuasaan kehakiman dan memiliki posisi sejajar dengan Mahkamah Agung. Mahkamah Konstitusi memiliki empat kewenangan dan satu kewajiban konstitusional, yaitu menguji undang-undang terhadap undang-undang dasar, memutus sengketa kewenangan lembaga negara yang kewenangannya diberikan oleh undang-undang dasar, memutus pembubaran partai politik; dan memutus 
perselisihan tentang hasil

pemilihan umum. Satu

kewajiban konstitusional

Mahkamah Konstitusi, yakni

memberikan putusan atas

pendapat

KedudukandanWewenangM ahkamahKonstitusi....

(NanangSriDarmadi) 681

682

Dewan Perwakilan Rakyat mengenai dugaan

pelanggaran oleh presiden/

dan atau wakil presiden

menurut Undang-Undang

Dasar.

Judicial review oleh

Mahkamah Konstitusi

sebagai kontrol antar

lembaga-lembaga negara

untuk terwujudnya cita

negara hukum yang

demokratis. Dalam 
melaksanakan

kewenangannya, Mahkamah Konstitusi telah menegaskan dirinya sebagai lembaga negara pengawal demokrasi dengan menjunjung prinsip peradilan yang menegakkan keadilan substantif dalam setiap putusannya. Keadilan di sini menjadi dasar filosofis pelaksanaan kewenangan Mahkamah Konstitusi.

Selain keadilan substantif, sebagai dasar filosofis dalam menjalankan kewenangan dan kewajibannya seperti yang diamanatkan oleh UndangUndang Dasar 1945, Mahkamah Konstitusi sebagai lembaga peradilan menerapkan prinsip keterbukaan dan transparansi (openness and 
transparency), serta akuntabilitas kepada publik. Keberadaan Mahkamah

Konstitusi ini juga tidak terlepas dari teori-teori hukum, antara lain teori kedaulatan, teori konstitusi, teori negara hukum demokrasi, teori kesejahteraan, teori keadilan, dan teori kepastian hukum.

Dasar yuridis kewenangan Mahkamah Konstitusi menguji undang-undang diatur dalam Pasal 24C ayat (1) Undang-Undang Dasar 1945 yang pada intinya menyatakan bahwa Mahkamah Konstitusi berwenang menguji undangundang terhadap UndangUndang Dasar. Pada tahap akhir, dengan disahkannya 
Undang- undang Nomor 24

Tahun 2003, maka

Mahkamah Konstitusi telah resmi dalam melaksanakan kewenangannya yang diberikan oleh UndangUndang Dasar 1945.

Keberadaan Mahkamah

Konstitusi dengan

kewenangan yang

dimilikinya, terpicu dengan

buruknya penyelenggaraan negara terutama saat masa orde baru yang ditandai dengan maraknya Jurnal Hukum Vol XXVI, No. 2, Agustus 2011

korupsi, kolusi, dan nepotisme, markus (makelar kasus), dicampakkannya nilai-nilai keadilan hukum, serta hak-hak konstitusional warga negara yang 
dilanggar.

\section{Saran}

\section{Keberadaan Mahkamah}

Konstitusi dalam kehidupan ketatanegaraan sangat penting dalam melindungi dan mengemban suara rakyat. Dengan putusanputusannya, Mahkamah Konstitusi merupakan jawaban konkrit atas segenap permasalahan yang terjadi di tengah-tengah masyarakat terhadap perundang-undangan yang dinilai warga bertentangan dengan konstitusi.

Tudingan adanya hakim tidak bersih di Mahkamah Konstitusi, dapat mencoreng citra Mahkamah Konstitusi, sehingga diperlukan komunikasi di antara para hakim konstitusi dan 
pengawasan baik internal

maupun eksternal di

Mahkamah Konstitusi. Hal itu

penting karena membiarkan

Mahkamah Konstitusi

sebagai lembaga peradilan

tanpa pengawasan akan

membahayakan. Putusan

Mahkamah Konstitusi

terhadap suatu perkara,

tidak jarang menimbulkan

pro dan kontra.

Keputusan Mahkamah

Konstitusi adalah keputusan

final dan mengikat yang

harus dihormati. Namun,

tentu hakim Mahkamah

Konstitusi tidak selalu

sempurna. Sudah pasti ada

sejumlah hal yang membuat

seorang hakim Mahkamah

Konstitusi menjadi kurang

teliti dalam mengambil

keputusan. Selain itu, tidak 
ada jaminan seratus persen hakim Mahkamah Konstitusi selalu bersih dan kuat menghadapi cobaan suap.

Oleh karena itu, untuk mengawasi dan menindak hakim Mahkamah Konstitusi yang diduga memberikan keputusan yang tidak obyektif atau melanggar kode etik, perlu segera dibentuk Badan Kehormatan Hakim untuk menindaklanjuti kasus pelanggaran kode etik. Dengan demikian, putusan hakim Mahkamah KedudukandanWewenangM ahkamahKonstitusi.... (NanangSriDarmadi) 683

Konstitusi dapat diuji keobyektifitasannya dan tidak merugikan pihak tertentu. 
Dari awal berdirinya,

Mahkamah Konstitusi sejak tahun 2003 sampai dengan tahun 2009 telah melaksanakan persidangan dari 404 perkara yang masuk ke bagian registrasi perkara, sebagaimana dalam Laporan Tahunan 2009 Mahkamah Konstitusi.

Banyaknya perkara yang masuk ke Mahkamah Konstitusi dari berbagai daerah perlu dilakukan pendistribusian untuk penanganan perkara tersebut. Dibentuknya perwalian di daerah-daerah di wilayah tertentu, bisa menjadi jalan keluar agar perkara yang masuk ke Mahkamah Konstitusi cepat terselesaikan dan memenuhi asas peradilan yang cepat, 
sederhana, dan murah.

684

Jurnal Hukum Vol XXVI, No.

2, Agustus 2011

DAFTAR PUSTAKA

Buku :

A.Kosasih Djahiri, 1971, Ilmu Politik, Parmaco, Bandung. Abdul Mukthie Fadjar, 2006, Hukum Konstitusi \& Mahkamah

Konstitusi, Konstitusi Press Jakarta dan Citra Media Yogyakarta.

Abdul Rasyid Thalib, 2006, Wewenang Konstitusi dan Implikasinya dalam Sistem Ketatanegaraan Republik Indonesia, Citra Aditya Bakti, Bandung.

Abu Daud Busroh dan Abu Bakar Busroh, 1991, Azasazas Hukum Tata Negara, 
Ghalia Indonesia, Jakarta.

Ahmad Syahrizal, 2006,

Peradilan Konstitusi, Suatu

Studi tentang Adjudikasi

Konstitusional Sebagai

Mekanisme Penyelesaian

Sengketa Normatif, Pradnya

Paramita, Jakarta.

Bagir Manan, 1995, Empat

Tulisan Tentang Hukum,

Program Pascasarjana BKU

Hukum Ketatanegaraan,

Universitas Padjajaran,

Bandung.

Bambang Sutiyoso, 2009,

Tata Cara Penyelesaian

Sengketa di Lingkungan

Mahkamah Konstitusi, UII

Press, Yogyakarta.

C.F. Strong, 2004,

Konstitusi-konstitusi Politik

Modern, Kajian Tentang

Sejarah \& Bentuk-bentuk

Konstitusi Dunia, Nuansa 
dan Nusamedia, Bandung.

C.S.T Kansil dan Christine

S.T. Kansil, 2010,

Perbandingan Hukum

Administrasi Negara, Rineka

Cipta, Jakarta.

Dahlan Thaib, 2009,

Ketatanegaraan Indonesia,

Perspektif Konstitusional,

Total Media, Yogyakarta.

, 2005, Teori dan Hukum

Konstitusi, Raja Grafindo

Persada, Jakarta.

Emeritus John Gilissen dan

Emeritus Frits Gorle, 2009,

Sejarah Hukum, Suatu

Pengantar, Refika Aditama,

Bandung.

G.S.Diponolo, 1975, Ilmu

Negara, Balai Pustaka,

Jakarta.

,QX .HQFDQD 6|DILqILH

Sistem Pemerintahan

Indonesia, Rineka 
Cipta, Jakarta.

KedudukandanWewenangM ahkamahKonstitusi....

(NanangSriDarmadi) 685

, 2004, ,OPX

3HPHULQWDKDQ GDQ \$O

4XUףDQ, Bumi Aksara,

Jakarta.

loanes Rakhmat, 2009,

Sokrates Dalam Tetralogi

Plato, Sebuah Pengantar

dan Terjemahan Teks,

Gramedia Pustaka Utama, jakarta.

Iriyanto A.Baso Ence, 2008,

Negara Hukum \& Hak Uji

Konstitusionalitas

Mahkamah Konstitusi,

Telaah Terhadap

Kewenangan Mahkamah

Konstitusi, Alumni, Bandung.

Ismail Sunny, 1986,

Pergeseran Kekuasaan 
Eksekutif, Aksara Baru, Jakarta.

Jimly Asshiddiqie, 2005,

Model-model Pengujian

Konstitusional di Berbagai

Negara, Konstitusi Press, Jakarta.

686

, 2006, Hukum Acara

Pengujian Undang-undang,

Sekretariat Jenderal dan

Kepaniteraan Mahkamah

Konstitusi Republik

Indonesia, Jakarta.

, 2006, Hukum Tata Negara dan Pilar-pilar Demokrasi,

Konstitusi Press, Jakarta.

, 2006, Kemerdekaan

Berserikat Pembubaran

Partai Politik dan Mahkamah

Konstitusi, Sekretariat

Jenderal dan Kepaniteraan

Mahkamah Konstitusi

Republik Indonesia, Jakarta. 
, 2006, Konstitusi dan

Konstitusionalisme

Indonesia, Sekretariat

Jenderal dan Kepaniteraan

Mahkamah Konstitusi

Republik Indonesia, Jakarta.

, 2006, Sengketa

Kewenangan Konstitusional

Lembaga Negara, Konstitusi

Press dan Syaamil Cipta

Media, Jakarta.

, 2008, Menuju Negara

Hukum yang Demokratis,

Sekretariat Jenderal dan

Kepaniteraan Mahkamah

Konstitusi Republik

Indonesia, Jakarta.

, 2008, Pokok-pokok Hukum

Tata Negara Indonesia Pasca

Reformasi, Buana IImu

Populer, Jakarta.

, 2009, Komentar Atas

Undang-Undang Dasar

Negara Republik Indonesia 
Tahun 1945, Sinar Grafika, Jakarta. Jurnal Hukum Vol XXVI, No. 2, Agustus 2011

, 2009, Pengantar Ilmu Hukum Tata Negara, Raja Grafindo, Jakarta. , 2010, Model-model Pengujian Konstitutional di Berbagai Negara, Sinar Grafika, Jakarta. K.C.Wheare, 2003, Konstitusi-konstitusi Modern, Terjemahan Muhammad Hardadi, Pustaka Eureka, Surabaya.

Laica Marzuki, 2006, Berjalan-jalan di Ranah Hukum, Sekretariat Jenderal dan Kepaniteraan Mahkamah Konstitusi, Jakarta. , 2006, Sudi Mampir di 
Mahkamah Konstitusi RI, 3-

XGLFLDO 5HYLHZ¥

$\%$ HUDFDUD GL

ODKNDPDK .RQVWLWXVL ,

Sekretariat Jenderal dan

Kepaniteraan Mahkamah

Konstitusi Republik

Indonesia, Jakarta.

Leonard W. Levy, 2005,

Judicial Review, Sejarah

Kelahiran, Wewenang, dan

Fungsinya dalam Negara

Demokrasi, Nuansa,

Bandung.

M.Hasbi Amiruddin, 2000,

Konsep Negara Islam

Menurut Fazlur Rahman, UII

Press, Yogyakarta.

Mahkamah Konstitusi

Republik Indonesia, 2008,

Naskah Komprehensif

Perubahan Undang-Undang

Dasar Negara Republik

Indonesia Tahun 1945, Latar 
Belakang, Proses, dan Hasil

Pembahasan 1999-2002,

Buku I, Latar Belakang,

Proses, dan Hasil Perubahan

UUD 1945, Sekretariat

Jenderal dan Kepaniteraan

Mahkamah Konstitusi,

Jakarta.

, 2008, Naskah

Komprehensif Perubahan

Undang- Undang Dasar

Negara Republik Indonesia

Tahun 1945, Latar Belakang,

Proses, dan Hasil

Pembahasan 1999-2002,

Buku II, Sendi-sendi/

Fundamen Negara,

Sekretariat Jenderal dan

Kepaniteraan Mahkamah

Konstitusi, Jakarta.

, 2008, Naskah

Komprehensif Perubahan

Undang- Undang Dasar

Negara Republik Indonesia 
Tahun 1945, Latar Belakang,

Proses, dan Hasil

Pembahasan 1999-2002,

Buku VI, Kekuasaan

Kehakiman, Sekretariat

Jenderal dan Kepaniteraan

Mahkamah Konstitusi,

Jakarta.

, 2009, Mengawal

Demokrasi Menegakkan

Keadilan Substantif, Laporan

Tahunan 2009, Sekretariat

Jenderal dan Kepaniteraan

Mahkamah Konstitusi,

Jakarta.

KedudukandanWewenangM ahkamahKonstitusi....

(NanangSriDarmadi) 687

, 2010, Hukum Acara

Mahkamah Konstitusi,

Sekretariat Jenderal dan

Kepaniteraan Mahkamah

Konstitusi, Jakarta. 
, 2010, Profil Mahkamah

Konstitusi, Sekretariat

Jenderal dan Kepaniteraan

Mahkamah Konstitusi,

Jakarta.

ODVGDU )DULG ODVףXGL

Syariah Konstitusi UUD 1945 dalam Perspektif Islam,

Pustaka Alfabet

bekerjasama dengan LaKIP,

Jakarta.

Masyhur Effendi, 2005,

Perkembangan Dimensi Hak

Asasi Manusia (HAM) dan

Proses Dinamika

Penyusunan Hukum Hak

Asasi Manusia (HAKHAM),

Ghalia Indonesia, Jakarta.

Miriam Budiardjo, 1991,

Dasar-dasar Ilmu Politik,

Gramedia, Jakarta.

Moh.Kusnardi dan Harmaily

Ibrahim, 1988, Pengantar

Hukum Tata 
Negara Indonesia, Pusat

Studi HTN Fakultas Hukum

UI, Jakarta. Moh.Mahfud

M.D., 2010, Konstitusi dan

Hukum dalam Kontroversi

Isu, Raja Grafindo Persada, Jakarta.

, 2010, Membangun Politik Hukum, Menegakkan

Konstitusi, Raja Grafindo

Persada, Jakarta.

, 2010, Perdebatan Hukum

Tata Negara Pasca

Amandemen Konstitusi, Raja

Grafindo Persada, Jakarta.

Muhammad Alim, 2010,

Asas-asas Negara Hukum

Modern dalam Islam, Kajian

Komprehensif Islam dan

Ketatanegaraan, LkiS,

Yogyakarta.

1LqPDWXO +XGD Negara

Hukum, Demokrasi \&

Judicial Review, UII Press, 
Yogyakarta.

, 2008, UUD 1945 dan

Gagasan Amandemen

Ulang, Raja Grafindo

Persada, Jakarta.

, 2010, Hukum Tata Negara

Indonesia, Raja Grafindo

Persada, Jakarta.

, 2010, Ilmu Negara, Raja

Grafindo Persada, Jakarta.

Padmo Wahjono, 1984,

Masalah Ketatanegaraan

Indonesia Dewasa

Ini, Ghalia Indonesia,

Jakarta.

688 Jurnal Hukum Vol XXVI,

No. 2, Agustus 2011

Paul Scholten, 2005, De Structuur Der

Rechtswetenschap, Struktur Ilmu Hukum, alih bahasa B.

Arief Sidharta, Alumni,

Bandung. 
P.J. Suwarno, 2009, Tata

Negara Indonesia, Dari

Sriwijaya sampai Indonesia

Modern, Universitas Sanata

Dharma, Yogyakarta.

Refly Harun et al., 2004,

Menjaga Denyut Konstitusi,

Konstitusi Perss, Jakarta.

Roberto M. Unger, 2010,

Teori Hukum Kritis, Posisi

Dalam Masyarakat Modern,

Nusa Media, Bandung.

Satjipto Rahardjo, 1986, IImu

Hukum, Alumni, Bandung.

Soehino, 2008, Hukum Tata

Negara, Teknik Perundang-

undangan,

Liberty, Yogyakarta.

Sri Soemantri, 1987,

Prosedur dan Sistem

Perubahan Konstitusi,

Disertasi, Alumni, Bandung.

, 1993, Susunan

Ketatanegaraan Menurut 
UUD 1945 dalam

Ketatanegaraan Indonesia

Dalam Kehidupan Politik

Indonesia, Sinar Harapan,

Jakarta.

1997, Hukum Uji Matriel,

Alumni, Bandung.

Sudikno Mertokusumo,

1998, Mengenal Hukum

Suatu Pengantar,

Liberty, Yogyakarta.

Ulin Najihah, 2008,

Penerapan Sistem

Pembuktian Di Mahkamah

Konstitusi, Fakultas Hukum

Universitas Islam Indonesia,

Yogyakarta.

W.Gulo, 2002, Metode

Penelitian, Gramedia

Widiasarana Indonesia,

Jakarta.

Wirjono Projodikoro, 1989,

Asas-asas Hukum Tata

Negara di Indonesia, Dian 
Rakyat, Jakarta.

Zainal Arifin Hoesein, 2009, Judicial Review di Mahkamah Agung RI, Tiga Dekade Pengujian Peraturan Perundang-undangan, Raja Grafindo Persada, Jakarta. KedudukandanWewenangM ahkamahKonstitusi.... (NanangSriDarmadi) 689

Peraturan Perundangundangan :

Undang-Undang Dasar

Negara Republik Indonesia

Tahun 1945. Undangundang Nomor 24 Tahun 2003 Tentang Mahkamah Konstitusi. Undang-undang Nomor 4 Tahun 2004 Tentang Kekuasaan Kehakiman. Undang-undang Nomor 3 Tahun 2009 Tentang Mahkamah Agung. 
Jurnal :

Bambang Sutiyoso,

Desember 2010,

Pembentukan Mahkamah

Konstitusi Sebagai Pelaku

Kekuasaan Kehakiman di

Indonesia, dalam Jurnal

Konstitusi Volume 7 Nomor

6, Sekretariat Jenderal dan

Kepaniteraan Mahkamah

Konstitusi, Jakarta.

Indra Perwira, dkk.,

November 2010, Budaya

Konstitusi (Constitutional

Culture) Dalam UUD 1945

Perubahan Dikaitkan Dengan

Gagasan Perubahan Kelima

UUD 1945, dalam Jurnal

Konstitusi Volume II Nomor

2, Mahkamah Konstitusi

Republik Indonesia.

690 Jurnal Hukum Vol XXVI,

No. 2, Agustus 2011 